\title{
When the skin speaks what HIV dictates: a series of particular cases of cutaneous manifestations in HIV
}

\author{
Anca Răducan ${ }^{1 *}$, Adina Alexandru1,2, Sorin Rugină ${ }^{3,4}$ \\ From The 10th Edition of the Scientific Days of the National Institute for Infectious Diseases "Prof Dr Matei \\ Bals" \\ Bucharest, Romania. 15-17 October 2014
}

\section{Background}

Recent data show that almost $75 \%$ of HIV patients have muco-cutaneous diseases, the proportion of patients with dermatoses being inversely proportional to the CD4 + and directly proportional to the stage of disease. Papulo-pustular eruption is the most common pruritic dermatosis in patients with HIV infection, followed by seborrheic dermatitis, psoriasis, molluscum contagiosum and drug reactions.

\section{Case report}

We report a series of cases of patients with skin diseases associated with HIV infection, which are distinguished by particular features and clinical course.

Case 1: 54 years old patient with generalized psoriasis and HIV-syphilis co-infection. Case 2: male patient, aged 32 years, with acrodermatitis continua of Hallopeau and HIV infection. Case 3: 34 years old female patient with papulo-pustular acne, molluscum contagiosum, plantar warts, cutaneous xerosis and HIV-HBV co-infection. Case 4: female patient aged 26 years with 20 years history of HIV infection and epidermodysplasia verruciformis for 10 years. Case 5: 25 years old male patient with excoriated and overinfected warts, hepatitis B and HIV infection. Case 6: Patient with HIV infection, seborrheic dermatitis and post herpes zoster scar. Case 7: Patient with HIV infection and pityriasis versicolor.

\section{Conclusion}

Most HIV patients can present with a variety of skin diseases throughout the evolution of HIV infection, as a result of achieved immunodeficiency or treatment. Patients undergoing HAART have a different clinical progress of HIV infections and therefore of dermatological

* Correspondence: anca_raducan@yahoo.com

${ }^{1}$ Colentina Clinical Hospital, Bucharest, Romania

Full list of author information is available at the end of the article manifestations, provided that the immune system's functionality is restored.

\section{Consent}

Written informed consent was obtained from all patients for publication of this Case report and any accompanying images. A copy of the written consent is available for review by the Editor of this journal.

\section{Authors' details}

${ }^{1}$ Colentina Clinical Hospital, Bucharest, Romania. ${ }^{2}$ Carol Davila University of Medicine and Pharmacy, Bucharest, Romania. ${ }^{3}$ Clinical Infectious Diseases Hospital of Constanța, Romania. "Faculty of Medicine, "Ovidius" University, Constanța, Romania.

\section{Published: 15 October 2014}

doi:10.1186/1471-2334-14-S7-P78

Cite this article as: Răducan et al:: When the skin speaks what HIV dictates: a series of particular cases of cutaneous manifestations in HIV. BMC Infectious Diseases 2014 14(Suppl 7):P78.

Submit your next manuscript to BioMed Central and take full advantage of:

- Convenient online submission

- Thorough peer review

- No space constraints or color figure charges

- Immediate publication on acceptance

- Inclusion in PubMed, CAS, Scopus and Google Scholar

- Research which is freely available for redistribution 